\title{
Irrigation and fertigation frequencies with nitrogen in the watermelon culture
}

\author{
Carlos Newdmar Vieira Fernandes (*); Benito Moreira de Azevedo; Joaquim Raimundo Nascimento Neto; \\ Thales Vinícius de Araújo Viana; Geocleber Gomes de Sousa
}

Universidade Federal do Ceará (UFC), Engenharia Agrícola, Caixa Postal 12.168, 60450-760 Fortaleza (CE), Brasil.

${ }^{*}$ ) Corresponding author: newdmar@gmail.com

Received: Dec. 9, 2013; Accepted: Mar. 8, 2014

\begin{abstract}
This study evaluates the influence of different irrigation frequencies and different nitrogen fertigation frequencies on the growth performance of the watermelon (Citrullus lanatus) culture. Two experiments were conducted at the Paraguay farm in the Cruz municipality, Ceará, Brazil. They was randomized blocks design with six treatments and four replications. The irrigation frequency experiment consisted of the application of different irrigation frequencies. The treatments were: DM - daily irrigation in the morning with 100\% daily dosage; DT - daily irrigation in the afternoon, with 100\% daily dosage; DMT - twice daily irrigation, with 50\% daily dosage in the morning and 50\% daily dosage in the afternoon; 2D - irrigation every two days; 3D - irrigation every three days and 4D - irrigation every four days. To the experiment with different nitrogen fertigation frequencies, the treatments used were: $2 \mathrm{~F}$ - 2 fertigations in a cycle; $4 \mathrm{~F}$ - 4 fertigations in a cycle; $8 \mathrm{~F}$ - 8 fertigations in a cycle; $16 \mathrm{~F}$ - 16 fertigations in a cycle; 32F - 32 fertigations in a cycle and 64F - 64 fertigations in a cycle. We evaluated the marketable yield (PC), fruit weight (M), polar diameter (DP), equatorial diameter (DE), shell thickness (EC) and soluble solids (SS). The irrigation frequency treatments influenced all variables significantly, with twice daily irrigation (DMT, 50\% in the morning and the 50\% in the afternoon) promoting the highest productivity $\left(69.79 \mathrm{t} \mathrm{ha}^{-1}\right)$. The different frequencies of fertigation also significantly influenced all variables, except for the shell thickness, the highest yield $\left(80.69 \mathrm{t} \mathrm{ha}^{-1}\right)$ being obtained with treatment 64 fertigations in a cycle.
\end{abstract}

Key words: Citrullus lanatus, irrigation management, chemigation, nitrogen fertilizing.

\section{Frequências de irrigação e fertirrigação com nitrogênio na cultura da melancia}

\begin{abstract}
Resumo
Com o objetivo de avaliar a influência de diferentes frequências de irrigação e fertirrigação nitrogenada no desempenho produtivo da cultura da melancia (Citrullus lanatus), realizaram-se dois experimentos no sítio Paraguai, município de Cruz, Ceará. O delineamento adotado foi o de blocos ao acaso com seis tratamentos e quatro repetições. No experimento com irrigação, os tratamentos consistiram na aplicação de diferentes frequências de irrigação, sendo: DM - diariamente (100\% de manhã); DT diariamente (100\% a tarde); DMT - diariamente (50\% de manhã e 50\% a tarde); 2D - a cada dois dias; 3D - a cada três dias; e 4D - a cada quatro dias. No experimento com diferentes frequências de fertirrigação nitrogenada, os tratamentos empregados foram: 2F - 2 fertirrigações no ciclo; 4F - 4 fertirrigações no ciclo; 8F - 8 fertirrigações no ciclo; $16 \mathrm{~F}$ - 16 fertirrigações no ciclo; 32F - 32 fertirrigações no ciclo; e 64F - 64 fertirrigações no ciclo. Avaliaram-se: produtividade comercial (PC); massa média do fruto (M); diâmetro polar (DP) e equatorial (DE); espessura da casca (EC); e teor de sólidos solúveis (SS). Os tratamentos com frequência de irrigação influenciaram significativamente todas as variáveis, sendo que a irrigação diária (50\% de manhã e 50\% a tarde) foi responsável pela maior produtividade $\left(69,79 \mathrm{t} \mathrm{ha}^{-1}\right)$. As diferentes frequências de fertirrigação também influenciaram significativamente todas as variáveis, com exceção da espessura da casca, a maior produtividade (80,69 t há-1) foi obtida com o tratamento com 64 fertirrigações no ciclo.
\end{abstract}

Palavras-chave: Citrullus lanatus, manejo da irrigação, quimigação, adubação nitrogenada.

\section{INTRODUCTION}

Watermelon (Citrullus lanatus (Thunb.) Nakai \& Matsum) is a cucurbit cultivated in many parts of Brazil and around the world. In 2009, the worldwide production of watermelon was 98 million tons with an average yield of $28.7 \mathrm{t} \mathrm{ha}^{-1}$. China is the largest producer, with 65 million tons, equivalent to $66.3 \%$ of world total (FAO, 2011).
That same year, Brazil was ranked as the fourth largest world producer with a total production of 2 million tons and an average yield of $20.1 \mathrm{tha}^{-1}$. The Northeast region accounts for $35.8 \%$ of the production, highlighting the states of Pernambuco and Bahia, which together account for $68.1 \%$ of the regional production. The state of Ceará in 
2009 reached a production of 51.3 tons being the eleventh national position and accounting for $6.8 \%$ of the Northeastern production, however, it is noteworthy that the state has the largest national productivity, $35 \mathrm{t} \mathrm{ha}^{-1}$ due to the growth of fertilized and irrigated farming, which is above the Brazilian and world average (IBGE, 2011).

The cultivation of watermelon has great socio-economic importance for the Brazilian Northeast for being done mainly by small farmers. Its easy handling and lower production cost, when compared to other vegetables such as melons, tomatoes, potatoes, peppers, among others, make watermelon an important crop for Brazil. The intensive demand of skilled rural workers, generates income and jobs and helps keep man in the field, as well as a good economic return to the producer (Oliveira et al., 2012).

Taking into account the ideal climatic conditions for the development of watermelon, the Northeast region stands out as the greatest potential for the development of this vegetable crop (Mousinho et al., 2003). In this region, the cultivation under irrigation has grown and allowed the producer to offer the best quality fruits, at the moment the price is more attractive to the consumer market.

In this sense, it is important to say that the localized irrigation systems have been widely used due to their water savings efficiency and for the lowest cost implementation, on the other hand, the system of drip irrigation generally restricts the root system of the plant, and therefore there is a constant requirement for nutrients to maintain production, and thus only fertigation has the ability to satisfy all plants' nutrient needs. Therefore, in tropical regions with low fertility soil and rainfall irregularity throughout the year, watermelon has a limited production, so that irrigation and fertilization can explain virtually all production potential of this crop in such environment (Fernandes and Prado, 2004).

Mousinho et al. (2003) point out that among the factors that influence the development of an agricultural crop, water and nitrogen deserve special attention. Thus, we should seek the efficient use of water without causing hydric stress in the plants, and provide nitrogen at the time of greatest nutritional need, keeping in the soil conditions to be used by future generations. These two inputs together represent about $10 \%$ of the production cost, providing the greatest variations in the income in the case of watermelon.

However, despite the increasing importance of the cultivation of watermelon in the country, Figueirêdo et al. (2009) report that factors that condition its yield and quality on irrigation management still need to be further investigated. According to these authors, the practice of irrigation should be used rationally, since the climatic conditions in the Northeast, high temperatures and low rainfall, and high levels of salts in irrigation waters have caused soil salinization.

With regard to the rational use of irrigation we must give special attention to irrigation management, determining accurately the water requirements of the crop without deficit or excess, as the blade and the most appropriate time to proceed with irrigation (Bilibio et al., 2010). The irrigation frequency, defined by the interval between two successive irrigations should be used in a way so as not to compromise the water needs of the plants in their different phenological stages (Sousa et al., 2014).

Reinforcing the hypothesis of this study, some researchers have shown significant results under different irrigation frequencies on different crops, soils and climatic conditions. For so we can mention Braz et al. (2009), Medeiros et al. (2006) and Valnir Júnior et al. (2010).

Another relevant aspect to the increase in Watermelon productivity is nitrogen fertilization. According to Andrade Júnior et al. (2006), like other cultures, watermelon has in mineral nutrition, one of the factors that directly contribute to the productivity and fruit quality, especially for being highly demanding in nitrogen, which increases the need for research on it. For Papadopoulos (1999), the split during the crop cycle and their application directly on the effective zone of the root system can increase the utilization efficiency. This statement corroborates Andrade Júnior et al. (2007) who reported that for several oleraceus species, the fertigation split has provided greater increases in productivity over conventional application.

For Santos et al. (2009), the constant search for a balance in the application of nitrogen $(\mathrm{N})$, together with the scarcity of studies on plant response and the effects on the production of quality fruits, increases the need for more research on the subject. Thus, starting with the assumption that the fractionation of applying water and nitrogen inputs through fertigation improves the utilization of these by the plant and provides higher yields. This study aimed to evaluate the influence of different irrigation frequencies and frequencies of $\mathrm{N}$ fertigation on growth performance of watermelon crop.

\section{MATERIAL AND METHODS}

The experiments were conducted from October to December 2010, in the sítio Paraguai, municipality of Cruz, located in the northern region of the state of Ceará. The total area cultivated with watermelon was $4.760 \mathrm{~m}^{2}(0.4760 \mathrm{ha})$, which was divided into two sub-areas of $2.380 \mathrm{~m}^{2}$ (0.2380 ha) corresponding to the two experiments.

According to the Köppen climate classification, the climate is of the Aw', kind, characterized as tropical rainy climate with average annual rainfall of $1,135.4 \mathrm{~mm}$, average temperature of $28.1^{\circ} \mathrm{C}$ and annual average relative humidity of $70 \%$ (Saraiva et al., 2013).

The soil in the area is classified as a Quartzipsament Neo Soil, well drained and sandy texture (EMBRAPA, 2006), whose chemical and physical characteristics of the soil showed: 
$\mathrm{pH}=4.9 ; \mathrm{Al}^{+3}=0.2 \mathrm{cmol} \mathrm{dm}_{\mathrm{c}}^{-3} ; \mathrm{Ca}^{+2}=0.8 \mathrm{cmol} \mathrm{dm}_{\mathrm{c}} \mathrm{dm}^{-3} ;$ $\mathrm{Mg}^{+2}=0.6 \mathrm{e} \mathrm{K}^{+}=0,1 \mathrm{cmol}_{c} \mathrm{dm}^{-3} ; \mathrm{P}=2 \mathrm{mg} \mathrm{dm}^{-3}$; fine sand content $=248400 \mathrm{~g} \mathrm{~kg}^{-1}$; coarse sand content $=675 \mathrm{~g} \mathrm{~kg}^{-1}$; silt content $=36 \mathrm{~g} \mathrm{~kg}^{-1}$; clay content $=400 \mathrm{~g} \mathrm{~kg}^{-1}$; specific mass $=1.52 \mathrm{~g} \mathrm{~cm}^{-3}$; and useful water $=0.0073 \mathrm{~cm}^{3} \mathrm{~cm}^{-3}$ (estimated with base on the values of field capacity and permanent wilting point). It was performed only a soil analysis which was representative of soil layer $0-30 \mathrm{~cm}$, since the root system of watermelon is more developed in the horizontal direction, concentrating in up to $30 \mathrm{~cm}$ below the ground surface (Rocha et al., 2011).

According to the analysis the water was classified as $C_{1} S_{1}$, in general, no limitations to the practice of providing irrigation, as recommended by FAO (Ayers and Westcot, 1994) indexes. The results obtained with chemical water analysis were: $\mathrm{Ca}^{+2}=0.9 \mathrm{mmol}_{\mathrm{c}} \mathrm{L}^{-1}$; $\mathrm{Mg}^{+2}=1.2 \mathrm{mmol}_{c} \mathrm{~L}^{-1} ; \mathrm{Na}^{+}=1.9 \mathrm{mmol}_{\mathrm{c}} \mathrm{L}^{-1}$; $\mathrm{K}^{+}=0,3 \mathrm{mmol} \mathrm{L}_{\mathrm{c}} \mathrm{L}^{-1} ; \mathrm{Cl}^{-}=4.2 \mathrm{mmol} \mathrm{L}_{\mathrm{c}} \mathrm{L}^{-1} ; \mathrm{SO}_{4}^{2-}=0 \mathrm{mmol}_{\mathrm{c}} \mathrm{L}^{-1}$; $\mathrm{HCO}_{3}{ }^{2-}=0.2 \mathrm{mmol}_{\mathrm{c}} \mathrm{L}^{-1} ; \mathrm{CO}_{3}{ }^{2-}=0 \mathrm{mmol}_{\mathrm{c}} \mathrm{L}^{-1} ; \mathrm{pH}=4.0$; RAS $=1.85 \mathrm{mmol} \mathrm{L}^{-1} ; \mathrm{CE}=0.44 \mathrm{dS} \mathrm{m}{ }^{-1}$.

The experiments were conducted in a complete randomized block design with six treatments and four blocks. In the experiment with irrigation the treatments adopted consisted in the application of water irrigation at different irrigation frequencies, being: DM - daily $(100 \%$ in the morning), DT - daily (100\% afternoon), DMT daily (50\% in the morning and $50 \%$ in the afternoon); $2 \mathrm{D}$ - every two days; 3D - every three days; $4 \mathrm{D}$ - every four days. For 2D, 3D and 4D treatments the amount of water applied corresponded to the sum of the ETc in the corresponding period. It means that the accumulated value of 2, 3 and 4 days, respectively. In treatments with a single irrigation during the day, this one was always performed in the morning around 8:00am. As for the treatment with split irrigation into two applications per day, besides the first ever held at the time described, the second was always performed around 14:00. In the experiment with fertigation the treatments used at different frequencies of fertigation with nitrogen being: $2 \mathrm{~F}-2$ fertigations in the cycle; $4 \mathrm{~F}-4$ fertigations in the cycle; $8 \mathrm{~F}-8$ fertigations in the cycle; $16 \mathrm{~F}-16$ fertigations in the cycle; $32 \mathrm{~F}-32$ fertigations in the cycle; 64F - 64 fertigations during the cycle. All the Fertirrigations were performed in the morning, always around 8:00am o'clock. It is noteworthy that none of the treatments presented solubility problems of the fertilizer used. For this experiment it was performed daily irrigation, which was the only source of water for the crop, since there was no rainfall during the growing period.

Also regarding all fertigation treatments started on planting and other applications throughout the crop cycle as follows: $2 \mathrm{~F}$ - (0 and $32 \mathrm{DAP})$; $4 \mathrm{~F}$ - (0, 16, 32 and $48 \mathrm{DAP})$; $8 \mathrm{~F}-(0,8,16, \ldots, 48$ and $56 \mathrm{DAP}) ; 16 \mathrm{~F}-(0,4,8, \ldots, 56$ and $60 \mathrm{DAP}) ; 32 \mathrm{~F}-(0,2,4, \ldots, 60$ and $62 \mathrm{DAP})$ and $64 \mathrm{~F}$ $-(0,1,2, \ldots, 63$ and $64 \mathrm{DAP})$. Using as a basis the duration of phenological stages of watermelon development found by Miranda et al. (2004), the applications corresponding to the treatment $2 \mathrm{~F}$ covered the initial and Growth stages. Treatment $4 \mathrm{~F}$ covered the Beginner, Intermediate and Growth phases, whereas other treatments 8F, 16F, 32F and $64 \mathrm{~F}$ covered all stages of watermelon development.

The plots occupied an individual area of $70 \mathrm{~m}^{2} 70 \mathrm{~m}^{2}$ $(35 \mathrm{~m} \times 2 \mathrm{~m})$, and consisted of 35 plants spaced $2.0 \mathrm{~m}$ between rows and $1.0 \mathrm{~m}$ between plants. The installation of the culture was performed by direct seeding, placing two seeds per hole of Crimson Sweet variety, to perform roughing seven days after sowing (DAS 7), leaving only one plant per hole, getting a booth 5,000 plants ha ${ }^{-1}$.

The quantification of fertilizers was based on soil analysis and recommendations proposed by Crisóstomo et al. (2002), advocating the application of nitrogen according to the absorptions of culture, being the amount of fertilizer split weekly as follows: 1st, 2nd, 3rd and 4th week - 10\% per week, 5 th and 6 th week $-15 \%$ per week, 7 th , 8 th and 9 th week $-10 \%$ per week. For treatment with daily fertigation, the dose of fertilizer applied weekly was divided by seven and the amount of fertilizer applied was equivalent to one day, and for the other treatments the amount of fertilizer applied at every fertigation was proportional to the number of days between two consecutive applications. The other nutrients were applied at once at the time of planting.

In both experiments all fertilizations were performed via fertigation and the fertilizers used were: urea $\left(120 \mathrm{~kg} \mathrm{ha}^{-1}\right.$ nitrogen), calcium nitrate (68 $\mathrm{kg} \mathrm{ha}^{-1}$ calcium), phosphoric acid (240 $\mathrm{kg} \mathrm{ha}^{-1}$ phosphorus), white potassium chloride (300 kg ha ${ }^{-1}$ potassium), magnesium sulphate $\left(23 \mathrm{~kg} \mathrm{ha}^{-1}\right.$ magnesium), boric acid ( $1 \mathrm{~g} \mathrm{plant}^{-1}$ boron) and zinc sulphate ( $2 \mathrm{~g}$ plant $^{-1}$ zinc). In calculating the amount of urea to be applied in installments was cashed the percentage of nitrogen already applied through the calcium nitrate.

Cultural practices were held as two hand weedings at 15 and 35 DAS; fruit thinning conducted between 40-50 DAS; monitoring of the phytosanitary and nutrition state conducted throughout the whole experiment; and hand harvesting conducted at 69 DAS for the two experiments.

The irrigation system was of the dripping kind, consisting of a lateral line per plant row. Each lateral line was $35 \mathrm{~m}$ long and $2 \mathrm{~m}$ spaced; composed by polyethylene dropper tube emitters spaced $0.4 \mathrm{~m}$ nominal flow rate of $1.6 \mathrm{~L} \mathrm{~h}^{-1}$. The amount of water applied in irrigation was estimated considering the crop evapotranspiration of the (ETc) culture obtained from the reference evapotranspiration (ETo), estimated by the evaporation of a class "A" tank installed in the vicinity of the crop area, approximately $20 \mathrm{~m}$ away, and the crop coefficient (Kc), according to Miranda et al. (2004) for each stage of development of the plant.

The variables analyzed after harvest were: commercial productivity $(\mathrm{CP})$; fruit mass $(\mathrm{FM})$, polar diameter $(\mathrm{PD})$, 
equatorial diameter (ED), shell thickness (ST) and soluble solids (SS).

The variables were subjected to analysis of variance by the test $F(p<0.01$ and $p<0.05)$. When verified statistical significant effect in the analysis of variance, the data obtained in the different treatments of qualitative nature were compared using the Tukey test $(\mathrm{p}<0.05)$ and the ones of quantitative nature were subjected to regression study, seeking to adjust equations that best represent the relationship between the variables and the treatments applied, being selected the mathematical models that showed the highest levels of greater significance and value of coefficient of determination $\left(\mathrm{R}^{2}\right)$, using for this the software SAEG 9.0 UFV (2005).

By coefficient between crop yield and total irrigation water applied during the crop cycle, it was determined the efficiency use of water (EUW), according to the equation below:

$$
\operatorname{EUW} \frac{\mathrm{Y}}{\mathrm{W}}
$$

in which,

EUW - efficient use of water, $\mathrm{kg} \mathrm{ha}^{-1} \mathrm{~mm}^{-1}$;

$\mathrm{Y}$ - crop yield $\mathrm{kg} \mathrm{ha}^{-1}$, and

$\mathrm{W}$ - total irrigation water applied during the cycle, $\mathrm{mm}$.

\section{RESULTS AND DISCUSSION}

The analysis of variance of the frequency of irrigation, for the variables studied, revealed that all of them responded significantly $(\mathrm{p}<0.01)$ different irrigation frequencies applied throughout the cycle.

The mean values for the variables analyzed, commercial productivity $(\mathrm{CP})$; fruit mass $(\mathrm{M})$, polar diameter $(\mathrm{PD})$, equatorial diameter (ED), shell thickness (ST) and soluble solids (SS) are present in table 1. With regard to business productivity, it is observed that the daily irrigation $(50 \%$ in the morning and $50 \%$ in the afternoon) gave the highest value $\left(69.79 \mathrm{tha}^{-1}\right)$, which was statistically higher than the other treatments, except for the daily irrigation $(100 \%$ in the morning). Similar to productivity, F, ED, PD, with daily irrigation treatments (DM, DA and DMA) did not differ statistically among each other, however, they differ from the others, and the $4 \mathrm{D}$ treatment (irrigation frequency every four days) was the one that had the lowest values. Regarding the EC treatments with daily irrigation DM, DMA and DA were superior to the treatment with higher irrigation frequency $4 \mathrm{D}$ but did not differ statistically from 2D and 3D treatments. As for SS only DM and DMA treatments differed from $4 \mathrm{D}$ treatment, but did not differ from the others.

These results show that the irrigation frequencies greater than one day, significantly reduces the productivity of watermelon grown in sandy soil under drip irrigation. Confirming the assertion Fernandes and Prado (2004) reported that as little watermelon resistant to soil water deficit since the frequent irrigation throughout the growing season has significantly increased fruit production. Sousa et al. (1999) point out that the high frequency of irrigation, besides increasing the efficiency of water use, favors the development of watermelon crop and thus enables greater productivity, since this practice tends to keep the soil in optimal moisture conditions.

The low values of the productive variables for irrigation frequencies of 2, 3 and 4 days $(2 \mathrm{D}, 3 \mathrm{D}$ and $4 \mathrm{D})$ can be possibly attributed to the occurrence of drought stress between irrigations. Similar behavior was found by Sousa et al. (2000) in experiments with the melon crop. The authors found reductions in productivity to irrigation frequencies of 3 and 4 days. However, Wendling and Gatto (2002) stated that irrigation with low frequency and high blades are not suitable for favoring the leaching of nutrients and the emergence of diseases. In semiarid regions, especially in sandy soils with low water holding capacity, such problems are accentuated, showing that watermelon in such conditions should be irrigated wherever possible, on a daily basis so that there is no compromise in crop yield case of the soil studied, since it has a low water retention capacity $\left(0.0073 \mathrm{~cm}^{3} \mathrm{~cm}^{-3}\right)$.

Table 1. Database of commercial productivity (CP); fruit mass (FM), polar diameter (PD), equatorial diameter (ED), shell thickness (ST) and soluble solids (SS), in watermelon plants for different frequencies irrigation, Fortaleza, Ceará, 2010

\begin{tabular}{|c|c|c|c|c|c|c|}
\hline \multirow[b]{2}{*}{ Treatment } & \multicolumn{6}{|c|}{ Variable } \\
\hline & $\begin{array}{c}\text { CP } \\
\left(\mathrm{t} \mathrm{ha}^{-1}\right)\end{array}$ & $\begin{array}{l}\text { FM } \\
\text { (g) }\end{array}$ & $\begin{array}{l}\text { ED } \\
(\mathrm{cm})\end{array}$ & $\begin{array}{l}\text { PD } \\
(\mathrm{cm})\end{array}$ & $\begin{array}{c}\text { ST } \\
(\mathrm{cm})\end{array}$ & $\begin{array}{c}\text { SS } \\
\left({ }^{\circ} \text { Brix }\right)\end{array}$ \\
\hline DM & $64.66 \mathrm{ab}$ & $9.89 \mathrm{a}$ & $23.99 \mathrm{a}$ & $29.48 a b$ & $2.33 \mathrm{a}$ & $11.00 \mathrm{a}$ \\
\hline DT & 57.44 bc & $9.74 \mathrm{a}$ & $23.52 \mathrm{a}$ & $29.81 \mathrm{a}$ & $2.25 \mathrm{a}$ & $10.63 a b$ \\
\hline DMT & 69.79 a & $10.20 \mathrm{a}$ & $23.88 \mathrm{a}$ & $30.36 \mathrm{a}$ & $2.20 \mathrm{a}$ & $10.95 \mathrm{a}$ \\
\hline $2 \mathrm{D}$ & 49.86 c & $8.39 \mathrm{~b}$ & $22.76 \mathrm{~b}$ & $28.12 b c$ & $1.98 a b$ & $10.68 a b$ \\
\hline $3 D$ & $48.03 \mathrm{~cd}$ & $8.15 b$ & $22.60 \mathrm{~b}$ & 28.09 c & $1.91 \mathrm{ab}$ & $10.03 a b$ \\
\hline $4 \mathrm{D}$ & $39.58 \mathrm{~d}$ & $7.07 \mathrm{c}$ & $21.51 \mathrm{c}$ & $27.00 \mathrm{c}$ & $1.73 \mathrm{~b}$ & $9.60 \mathrm{~b}$ \\
\hline Média & 54.89 & 8.91 & 23.04 & 28.81 & 2.06 & 10.48 \\
\hline
\end{tabular}

Means followed by the same letter in the column do not differ by Tukey test, p<0,05. DM - daily ( $100 \%$ in the morning), DT - daily ( $100 \%$ afternoon), DMT - daily ( $50 \%$ in the morning and $50 \%$ in the afternoon); $2 \mathrm{D}$ - every two days; $3 \mathrm{D}$ - every three days; $4 \mathrm{D}$ - every four days 
The analysis of variance for fertigation with nitrogen, showed a significant difference $(\mathrm{p}<0.01)$ in all variables, except to the shell thickness (ST).

In figures $1 \mathrm{a}, \mathrm{b}$, is observed the result of business productivity variable and weight of the fruit of the watermelon crop due to different frequencies of fertigation with nitrogen at $69 \mathrm{DAP}$, and was the most appropriate linear model with $\mathrm{R}^{2}$ of 0.93 and 0.87 , respectively.

With the model found it was estimated the maximum yield of watermelon in $82.95 \mathrm{tha}^{-1}$, corresponding to treatment with daily fertigation (64F) irrigated daily. Such productivity is close to those reported by Andrade Júnior et al. (2007) and Morais et al. (2008) since these authors found yields of the order of $76.19 \mathrm{tha}^{-1}$ and $77.803 \mathrm{tha}^{-1}$, respectively, when working with a culture of drip irrigation watermelon.

Pinto et al. (1994) working with another vegetable crop, the cultivation of melon, found a significant difference in frequency of nitrogen drip fertigation in commercial fruit production. According to these authors the daily frequency provided better results compared to the frequency of three days. Andrade Júnior et al. (2007) reported that for several oleraceous species, such as melon, split fertigation has provided greater increases in productivity over conventional application, being the statement consistent with which was observed in this study.

With respect to the fruit weight, obtained from the model it was estimated the maximum value at $11.62 \mathrm{~kg}$ for the treatment 64F. Grangeiro and Cecílio Filho (2004) and Grangeiro et al. (2005) observed that $\mathrm{N}$ was the second most exported element by the fruit, highlighting the importance of that nutrient in watermelon production capacity, and explaining the response observed in this study.

The regression analysis for the variables equatorial diameter (ED), polar diameter (PD) and soluble solids (SS) are shown in figure $2 \mathrm{a}, \mathrm{b}, \mathrm{c}$. It is observed that for all variables the function which best fit was the linear type with correlation coefficients of $0.74,0.92$ and 0.69 , respectively. The maximum values estimated by the models found for these variables were $25.14 \mathrm{~cm}, 30.81 \mathrm{~cm}$ and 11.79 Brix, respectively, all corresponding to treatment with 64 fertigations in the cycle.

Work carried out by Padilla (1998) reveals that one of the characteristics of fertigation is to put the ions in the soil solution in easily assimilated way by the crops, thus there is a stabilization and improvement of the cation exchange capacity (CEC) of the soil. Thus, the application of fertilizers in smaller quantities at a time and more often results in better availability of nutrients to the plant, a fact confirmed by the results found in this study, since all variables had the best answer for most fertigation frequency.

The best responses observed for the higher frequency of fertigation may also be a result of reduced losses caused by the split fertilization during the growing cycle, since the soil of the experimental area has low nutrient retention capacity $\left(\mathrm{CEC}=1.7 \mathrm{cmol}_{\mathrm{c}} \mathrm{dm}^{-3}\right)$. As well as their application directly
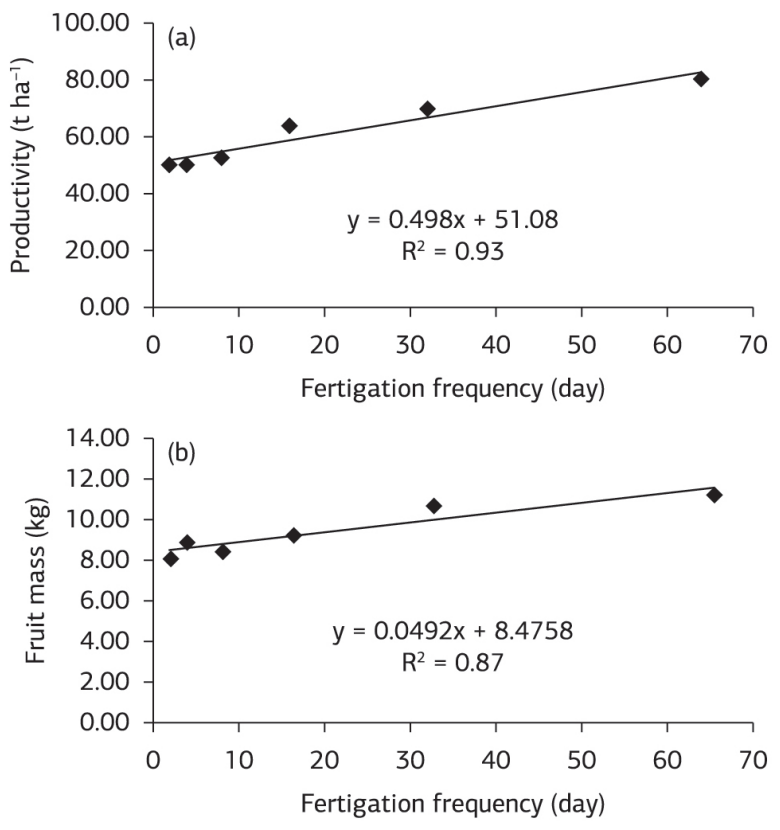

Figure 1. Commercial productivity (a) and fruit mass (b) in watermelon plants for different frequencies of fertigation with nitrogen, Fortaleza, Ceará, 2010.
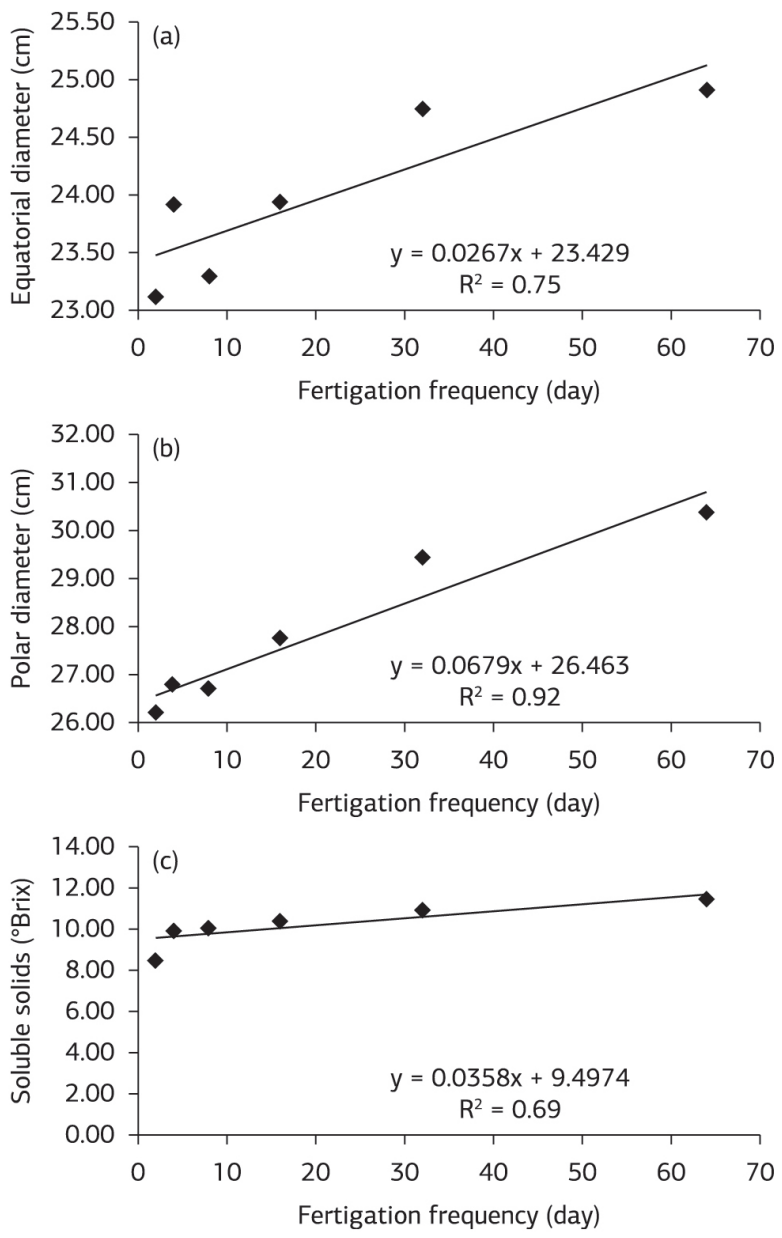

Figure 2. Equatorial diameter (a), polar diameter (b), and soluble solids (c) in watermelon plants for different frequencies of fertigation with nitrogen, Fortaleza, Ceará, 2010. 
Table 2. Efficiency use of water for watermelon crop for different irrigation frequencies, Fortaleza, Ceará, 2010

\begin{tabular}{|c|c|c|c|c|}
\hline Treatment & $\begin{array}{l}\text { Irrigation depth } \\
\text { (mm) }\end{array}$ & $\begin{array}{l}\text { Productivity } \\
\left(\mathrm{kg} \mathrm{ha}^{-1}\right)\end{array}$ & $\begin{array}{l}\text { Efficient use of water } \\
\qquad\left(\mathrm{kg} \mathrm{mm}^{-1}\right)\end{array}$ & $\begin{array}{c}\text { Percentage change } \\
(\%)\end{array}$ \\
\hline DM & 394 & 64.658 & 164.11 & 63.36 \\
\hline DT & 394 & 57.435 & 145.77 & 45.11 \\
\hline DMT & 394 & 69.788 & 177.13 & 76.32 \\
\hline $2 \mathrm{D}$ & 394 & 49.855 & 126.54 & 25.96 \\
\hline $3 D$ & 394 & 48.025 & 121.89 & 21.34 \\
\hline
\end{tabular}

in the effective area of the root system, since the irrigation method employed was the one localized by drip irrigation and the irrigation time adopted was always that necessary to the application of the depth required by the culture in order to prevent possible losses by percolation. This statement reinforces the conclusion of Andrade Júnior et al. (2006); Papadopoulos (1999). For these researchers, the nutrients are supplied at the moment and in adequate quantities for plants, increasing the fertilizer efficiency, since plants nutrients' requirements vary at each stage of development.

According to Fernandes and Prado (2004), results that demonstrate the application of fertilizers through irrigation water by localized system, allied to fractionation of nitrogen doses, can optimize the production system of Watermelon which seeks excellence in both production and fruit quality.

Relating the average productivity of each irrigation frequency, with the total amount of water applied, there is the efficiency of water use. In table 2 it can observed this efficiency and its variation percentage compared to the lowest value.

It is observed that the highest water use efficiency (177.13 $\mathrm{kg} \mathrm{ha}^{-1} \mathrm{~mm}^{-1}$ ) was obtained with the treatment where irrigation was daily and parceled (DPI) and the same treatment showed greater percentage increase compared to treatment with lower efficiency $(76.32 \%)$.

The water depth parceling in two daily applications provided an increment $31.21 \%$ above the one provided by the treatment with daily irrigation applied in the afternoon (DA) and $12.96 \%$ higher than the increment of treatment with daily irrigation in the morning (DM).

\section{CONCLUSION}

Through the results found in this study, it can be stated that in semi-arid regions, in soils of sandy texture with low retention capacity of water and nutrients, watermelon, should be irrigated and fertigated daily in order to obtain the best performance of the culture.

\section{REFERENCES}

ANDRADE JÚNIOR, A.S.; DIAS, N.S.; FIGUEIREDO JÚNIOR, L.G.M.; RIBEIRO, V.Q.; SAMPAIO, D.B. Produção e qualidade de frutos de melancia à aplicação de nitrogênio via fertirrigação. Revista Brasileira de Engenharia Agrícola e Ambiental, v.10, p.836-841, 2006. http://dx.doi.org/10.1590/S1415-43662006000400008

ANDRADE JÚNIOR, A.S.; DIAS, N.S.; LIRA, R.B.; FIGUEREDO JUNIOR, L.G.M.; DANIEL, R. Frequência de aplicação de nitrogênio e de potássio via água de irrigaçấo por gotejamento na cultura da melancia em Parnaíba, PI. Agropecuária Científica no Semiárido, v.3, p.1-7, 2007. Disponível em: <http://www.cstr.ufcg.edu.br/acsa/ artigos/Artigo_20.pdf>.

AYERS, R.S.; WESTCOT, D.W. Water quality for agriculture. 3rded. Rome: FAO, 1994. 174p. (Irrigation and Drainage Paper, n.29).

BILIBIO, C.; CARVALHO, J.A.; MARTINS, M.; REZENDE, F.C.; FREITAS, E.A.; GOMES, L.A.A. Desenvolvimento vegetativo e produtivo da berinjela submetida a diferentes tensōes de água no solo. Revista Brasileira de Engenharia Agrícola e Ambiental, v.14, p.730735, 2010. http://dx.doi.org/10.1590/S1415-43662010000700007

BRAZ, V.B.; RAMOS, M.M.; ANDRADE JÚNIOR, A.S.; SOUSA, C.A.F.; MANTOVANI, E.C. Níveis e frequências de irrigação na limeira 'Tahiti' no estado do Piauí. Revista Ceres, v.56, p.611-619, 2009. http://www.ceres.ufv.br/ceres/revistas/V56N005P08908.pdf

CRISÓSTOMO, L.A.; SANTOS, A.A.; RAIJ, B.V.; FARIA, C.M.B.; SILVA, D.J.; FERNANDES, F.A.M.; SANTOS, FJ.S; CRISÓSTOMO, J.R.; FREITAS, J.A.D.; HOLANDA, J.S.; CARDOSO, J.W.; COSTA, N.D. Adubação, Irrigação, Híbridos e Práticas Culturais para o Meloeiro no Nordeste. Fortaleza: Embrapa Agroindústria Tropical, 2002. 21p. (Circular Técnica, n.14). Disponível em: <http://www.ceinfo.cnpat. embrapa.br/arquivos/artigo_2852.pdf>.

EMPRESA BRASILEIRA DE PESQUISA AGROPECUÁRIA - EMBRAPA. Sistema brasileiro de classificação de solos. 2.ed. Rio de Janeiro: Embrapa Solos. 2006. 306p.

FERNANDES, F.M., PRADO, R.M. Fertirrigação da cultura da melancia. In: BOARETTO, A.E.; VILLAS BOAS, R.; SOUZA, W.F.; PARRA, L.R.V. (Eds.) Fertirrigaçăo: teoria e prática. Piracicaba, 2004. v.1, p.632-653. CD-Rom. Disponível em: <http://www.nutricaodeplantas. agr.br/site/culturas/melancia/melancia_4_9.pdf>.

FIGUEIRÊDO, V.B.; MEDEIROS, J.F.; ZOCOLER, J.L.; ESPINOLA SOBRINHO, J. Evapotranspiração da cultura da melancia irrigada com água de diferentes salinidades. Engenharia Agrícola, v.29, p.231240. 2009. http://dx.doi.org/10.1590/S0100-69162009000200006

FOOD AND AGRICULTURE ORGANIZATION OF THE UNITED NATIONS - FAO. Faostat database results. 2011. Disponível em: <http://faostat.fao.org>. Acesso em: 11 ago. 2011. 
GRANGEIRO, L.C.; CECÍLIO FILHO, A.B. Acúmulo e exportação de macronutrientes pelo híbrido de melancia Tide. Horticultura Brasileira, v.22, p.93-97, 2004. http://dx.doi.org/10.1590/S010205362004000100019

GRANGEIRO, L.C.; MENDES, M.A.S.; NEGREIROS, M.Z.; SOUZA, J.O.; AZEVÊDO, P.E. Acúmulo e exportação de nutrientes pela cultivar de melancia mickylee. Revista Caatinga, v.18, p.73-81, 2005. Disponível em: <http://www.redalyc.org/pdf/2371/237121137002.pdf>.

INSTITUTO BRASILEIRO DE GEOGRAFIA E ESTATÍSTICA - IBGE. Levantamento sistemático da produção agrícola. IBGE, 2011. Disponível em: <http://www.sidra.ibge.gov. br>. Acesso em: 11 ago. 2011.

MEDEIROS, J.F.; SILVA, M.C. C.; CÂMARA NETO, F.G.; ALMEIDA, A.H.B.; SOUZA, J.O. NEGREIROS, M.Z.; SOARES, S.P.F. Crescimento e produçáo do meláo cultivado sob cobertura de solo e diferentes frequências de irrigação. Revista Brasileira de Engenharia Agrícola e Ambiental, v.10, p.792-797, 2006. http:// dx.doi.org/10.1590/S1415-43662006000400002

MIRANDA, F.R.; OLIVEIRA, J.J.G.; SOUZA, F. Evapotranspiração máxima e coeficientes de cultivo para a cultura da melancia irrigada por gotejamento. Revista Ciência Agronômica, v.35, p.36-43, 2004. http:// www.ccarevista.ufc.br/site/artigos_lista.php?sel=2004\&sel $2=1 \&$ sel3 $3=35$

MOUSINHO, F.E.P.; COSTA, R.N.T.; SOUSA, F.; GOMES FILHO, R.R. Função de resposta da melancia à aplicação de água e nitrogênio para as condiçóes edafoclimáticas de Fortaleza, CE. Irriga v.8, p.264-272. 2003. Disponível em: <http://200.145.140.50/ojs1/ viewarticle.php?id=126\&layout $=$ abstract $>$.

MORAIS, N.B.; BEZERRA, F.M.L.; MEDEIROS, J.F.; CHAVES, S.W.P. Resposta de plantas de melancia cultivadas sob diferentes níveis de água e de nitrogênio. Revista Ciência Agronômica, v.39, p.369377, 2008. Disponível em: <http://www.ccarevista.ufc.br/seer/index.

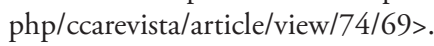

OLIVEIRA, P.G.F.; MOREIRA, O.C.; BRANCO, L.M.C.; COSTA, R.N.T.; DIAS, C.N. Eficiência de uso dos fatores de produção água e potássio na cultura da melancia irrigada com água de reuso. Revista Brasileira de Engenharia Agrícola e Ambiental, v.16, p.153-158, 2012. http://dx.doi.org/10.1590/S1415-43662012000200004

PADILLA, W.A. Factores que limitan el crecimiento y desarrollo de las plantas. Segundo Curso Internacional de Fertirrigacion en cultivos protegidos. Quito: Universidade San Francisco de Quito, 1998. p.1-10.

PAPADOPOULOS, I. Fertirrigação: situação atual e perspectivas para o futuro. In: FOLEGATTI, M.V. (Coord.). Fertirrigação: citrus, flores, hortaliças. Guaíba: Agropecuária, 1999. p.11-74.
PINTO, J.M.; SOARES, J.M.; PEREIRA, J.R.; CHOUDHURY, E.M.; CHOUDHURY, M.M. Efeitos de períodos e de frequências da fertirrigação nitrogenada na produção de melão. Pesquisa Agropecuária Brasileira, v.29, p.1345-1350, 1994. Disponível em: <http://seer.sct. embrapa.br/index.php/pab/article/view/4183/1474>.

ROCHA, M.R.; ELTZ, F.L.F.; SANTOS, M.S.; ROCHA, P.V.; GOULART, R.Z. Produtividade, qualidade dos frutos e distribuiçáo do sistema radicular da melancia em diferentes sistemas de cultivo. Revista Brasileira de Ciências do Solo, v.35, p.1377-1386, 2011. http://dx.doi.org/10.1590/S0100-06832011000400032

SANTOS G.R.; CASTRO NETO M.D.; ALMEIDA H.S.M.; RAMOS L.N.; SARMENTO R.A.; LIMA S.O.; ERASMO E.A.L. Effect of nitrogen doses on disease severity and watermelon yield. Horticultura Brasileira, v.27, p.330-334. 2009. http://dx.doi.org/10.1590/S010205362009000300012

SARAIVA, K.R., BEZERRA, F.M. L.; SOUZA, F.; CAMBOIM NETO, L.F. Aplicação do "ISAREG" no manejo da irrigaçáo na cultura da melancia no Baixo Acaraú, Ceará. Revista Ciência Agronômica, v.44, p.53-60, 2013. http://dx.doi.org/10.1590/S1806-66902013000100007

SOUSA, G.G.; AZEVEDO, B.M.; FERNANDES, C.N.V.; VIANA, T.V.A.; SILVA, M.L.S. Growth, gas exchange and yield of peanut in frequency of irrigation. Revista Ciência Agronômica, v.45, p.2734, 2014. http://dx.doi.org/10.1590/S1806-66902014000100004

SOUSA, V.F.; COÊLHO, E.F.; ANDRADE JUNIOR, A.S.; FOLEGATTI, M.V.; FRIZZONE, J.A. Eficiência do uso da água pelo meloeiro sob diferentes frequências de irrigaçáo. Revista Brasileira de Engenharia Agrícola e Ambiental, v.2, p.183-188, 2000. http:// dx.doi.org/10.1590/S1415-43662000000200009

SOUSA, V.F.; COÊLHO, E.F.; SOUZA, V.A.B. Frequência de irrigaçáo em meloeiro cultivado em solo arenoso. Pesquisa Agropecuária Brasileira, v.34, p.659-664, 1999. http://dx.doi.org/10.1590/S0100204X1999000400018

WENDLING, I.; GATTO, A. Substratos, adubação e irrigação na produção de mudas. Viçosa: Aprenda Fácil, 2002. 166p.

UNIVERSIDADE FEDERAL DE VIÇOSA - UFV. SAEG - Sistema para análises estatísticas. versão 9.0. Viçosa, 2005. CD-ROM.

VALNIR JÚNIOR, M; SOARES, F.A.L.; CARVALHO, C.M.; LIMA, S.C.R.U.; GOMES FILHO, R.R. Eficiência do uso da água pelo meloeiro sob diferentes lâminas e frequências de irrigação. Agropecuária Técnica, v.31, p.32-40, 2010. Disponível em: <http://periodicos.ufpb. br/ojs/index.php/at/article/view/3763/3655>. 